\title{
Restricted infection of xenotropic murine leukemia virus-related virus in human lymphoid tissue
}

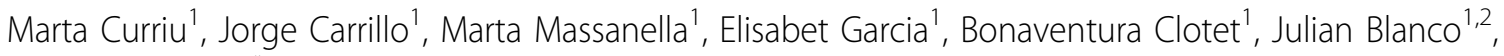 \\ Cecilia Cabrera ${ }^{1,2^{*}}$ \\ From 15th International Conference on Human Retroviruses: HTLV and Related Viruses \\ Leuven and Gembloux, Belgium. 5-8 June 2011
}

\section{Background}

Xenotropic murine leukemia virus-related virus (XMRV) infects different human cells in vitro. In this study the pathogenic effect of XMRV in lymphoid tissue was investigated by infection of human tonsil histocultures.

\section{Materials and methods}

Human tonsils were obtained from healthy donors, dissected into small blocks and cultured on top of gelfoams. Tissue blocks were left uninfected or infected with an XMRV stock obtained from a 22Rv1 cell culture supernatant in the presence or the absence of AZT or Raltegravir. Viral infection was evaluated by PCR at different times in the cells migrating out the tissue and at day 14 in tissue cells. In addition, tissue cells were immunophenotyped and the expression of XMRV envelope protein was analyzed by western blot.

\section{Results}

Cells migrating out the tissue and tissue cells were positive for XMRV and both AZT and Raltegravir blocked the detection of viral DNA. Despite the presence of XMRV DNA, tissue lysates exhibited undetectable expression of XMRV env proteins by WB. XMRV infection did not modify the percentage of CD3 (63 and 64 in $\mathrm{XMRV}$ - and XMRV + tissue, respectively), CD4 (47 vs 48), CD8 (20 vs 19), or CD19 cells (29 vs 27) neither the naive/memory cell ratio, nor immune activation markers, as evaluated by the expression of HLA-DR and CD38.

\section{Conclusions}

XMRV could specifically infect human lymphoid tissue cells although this process does not culminate in an

\footnotetext{
* Correspondence: ccabrera@irsicaixa.es

${ }^{1}$ Fundación irsiCaixa, Badalona, Barcelona, Spain

Full list of author information is available at the end of the article
}

explicit productive infection. This infection did not result in changes of $\mathrm{T}$ or $\mathrm{B}$ cells nor in immune activation, suggesting that lymphoid tissue could latently support XMRV infection.

\section{Author details}

${ }^{1}$ Fundación irsiCaixa, Badalona, Barcelona, Spain. ${ }^{2}$ Institut d'Investigació en Ciències de la Salut Germans Trias i Pujol, Badalona, Barcelona, Spain.

Published: 6 June 2011

doi:10.1186/1742-4690-8-S1-A208

Cite this article as: Curriu et al.: Restricted infection of xenotropic murine leukemia virus-related virus in human lymphoid tissue. Retrovirology 20118 (Suppl 1):A208.
Submit your next manuscript to BioMed Central and take full advantage of:

- Convenient online submission

- Thorough peer review

- No space constraints or color figure charges

- Immediate publication on acceptance

- Inclusion in PubMed, CAS, Scopus and Google Scholar

- Research which is freely available for redistribution

Submit your manuscript at www.biomedcentral.com/submit
C Biomed Central

\section{Ciomed Central}

(c) 2011 Curriu et al; licensee BioMed Central Ltd. This is an open access article distributed under the terms of the Creative Commons Attribution License (http://creativecommons.org/licenses/by/2.0), which permits unrestricted use, distribution, and reproduction in any medium, provided the original work is properly cited. 